\title{
PENERAPAN BAHAN AJAR BANGUN RUANG TABUNG BERBASIS PENDEKATAN RME TERHADAP KEMAMPUAN PEMECAHAN MASALAH MATEMATIS SISWA
}

\author{
${ }^{1}$ Sapti Handayani \\ ${ }^{1}$ (Pendidikan Matematika, Fakultas Keguruan Dan Ilmu Pendidikan, Universitas Muhammadiyah Sukabumi) \\ ${ }^{1}$ handayanisapti4@gmail.com
}

\begin{abstract}
ABSTRAK
Penelitian ini bertujuan untuk mengetahui penggunaan bahan ajar matematika pada materi bangun ruang tabung berbasis pendekatan RME terhadap kemampuan pemecahan masalah matematis siswa. Metode penelitian yang digunakan dalam penelitian ini adalah metode kualitatif dengan jenis penelitian studi kepustakaan. Dari hasil tersebut dapat disimpulkan bahwa penggunaan bahan ajar matematika pada materi bangun ruang tabung berbasis pendekatan RME berpengaruh positif terhadap kemampuan pemecahan masalah matematika, hal ini disebabkan karena dalam bahan ajar tersebut dapat 1) Bahan ajar memfasilitasi siswa dalam menemukan kembali penemuan konsep matematika pada materi bangun ruang tabung, 2) Siswa diberikan permasalahan matematika yang berkaitan dengan materi bangun ruang tabung dengan masalah nyata ataupun benda nyata di sekitarnya, 3) siswa termotivasi ikut pembelajaran karena bahan ajar yang digunakan dikaitkan dengan permasalahan yang ada di sekitar dan dikerjakan secara berkelompok, dan 4) siswa akan termotivasi untuk berdiskusi mengeluarkan pendapatnya dalam kelompoknya maupun antar kelompok mengenai konsep matematika pada materi bangun ruang tabung.

Kata Kunci : rme, materi bangun ruang tabung, bahan ajar matematika berbasis pendekatan rme, kemampuan pemecahan masalah.
\end{abstract}

\section{PENDAHULUAN}

Sebagai salah satu mata pelajaran di SMP yang terus menerus berkembang dari waktu ke waktu, matematika menjadi lebih bersifat teoritis dan abstrak. Sifat tersebut yang membuat siswa merasakan bahwa matematika adalah mata pelajaran yang membosankan dan sulit serta siswa tidak mengetahui dan merasakan manfaat dari matematika itu sendiri. Matematika berfungsi mengembangkan kemampuan mengkomunikasikan gagasan dengan bahasa yang dapat berupa model matematika, kalimat matematika, diagram, grafik atau tabel (Depdiknas, 2005). Matematika sebagai salah satu ilmu dasar merupakan mata pelajaran yang wajib diajarkan pada semua jenjang pendidikan, baik sekolah dasar, sekolah menengah maupun perguruan tinggi. Belajar untuk pembelajaran matematika dapat dianggap sebagai proses yang berkelanjutan dan seumur hidup yang berasal dari pengalaman yang diperoleh sebagai pembelajaran matematika di sekolah, Antti Viholainen, Mervi Asikainen \& Pekka E.Hirvonen (2014: 159).

Ilmu pembelajaran matematika adalah suatu pelajaran yang sangat luas cakupannya. Bukan hanya sekedar untuk dapat berhitung saja ataupun memasukkan angka-angka ke dalam rumus-rumus saja. Tetapi juga mencakup pada beberapa kompetensi yang dapat menjadikan siswa dapat memahami dan mengerti mengenai konsep dasar matematika. Dalam pembelajaran, matematika memerlukan kemampuan memahami konsep matematika. Dengan kemampuan pemahaman konsep, diharapkan siswa mudah memahami dan menyelesaikan persoalan matematika. Pada (Depdiknas, 2006), dengan mengajukan masalah kontekstual, siswa secara bertahap dapat dibimbing untuk menguasai konsep-konsep matematika, yaitu mengkondisikan siswa untuk menemukan kembali rumus, konsep atas prinsip dalam matematika melalui bimbingan guru. Dalam proses pembelajaran tersebut, dapat melatih berpikir seseorang secara logis, kritis dan kreatif. Matematika mempelajari tentang pola keteraturan mengenai struktur yang terorganisir. Oleh karenanya, matematika dapat masuk dalam kehidupan manusia dalam segi apapun. Baik itu yang paling kompeks ataupun sederhana.

Mengembangkan segala kemampuan matematika siswa dalam memperoleh hasil belajar yang maksimal, merupakan tujuan dari pembelajaran matematika. dengan memaksimalkan kemampuan memecahkan masalah adalah salah satu target untuk mendapat hasil tersebut. Mengingat dalam pembelajaran matematika pemecahan masalah itu penting, maka kemampuan tersebut akan mendukung tercapainya tujuan dari kemampuan tersebut.

Kemampuan pemecahan masalah matematis ini merupakan segala kemampuan siswa dimana siswa berupaya untutuk mencari jalan keluar yang dilakukan dalam menuncapai tujuan, yang juga memerlukan kesiapan, kreativitas, pengetahuan dan kemampuan dengan aplikasinya dalam kehidupan sehari-hari. Pemecahan masalah dapat memberikan manfaat yang 
besar kepada siswa, karenanya kemampuan pemecahan masalah merupakan salah satu kemampuan yang harus dimiliki siswa. Jika siswa dapat memahami, memilih strategi yang tepat, kemudian menerapkannya dalam penyelesaian masalah, maka siswa dikatakan mampu memecahkan masalah matematika.

Pengaruh yang baik dari kemampuan pemecahan masalah matematis kepada hasil belajar matematika untuk menjadi lebih baik dan juga merupakan tujuan umum dari pengajaran matematika, karena dalam memecahkan persoalan baik dalam mata pelajaran lain ataupun kehidupan sehari-hari dapat dibantu oleh kemampuan pemecahan masalah matematis. Ketika kemampuan pemecahan masalahmatematis siswa kurang, maka dapat menyebabkan proses pembelajaran matematika itu tidak dapat mencapai tujuan hasil belajar yang diharapkan.

Banyak metode mengajar yang dapat digunakan pada pembelajaran matematika, tetapi tidak setiap pokok bahasan dari materi yang diajarkan cocok dengan setiap metode pembelajaran. Oleh karena itu, perlunya pemikiran yang lebih matang untuk memilih metode mengajar yang tepat untuk setiap pokok bahasan materi yang akan bervariasi jika menggunakan metode pembelajaran. Salah satu cara untuk mengembangkan kemampuan pemecahan masalah yaitu dapat dilakukan dengan mengembangkan LKS yang disusun pada rencana pelaksaan pembelajaran yang dilakukan oleh guru, yaitu menyusun LKS yang mengaitkan pada kehidupan sehari-hari dan yang berkaitan dengan menemukan kembali konsep matematika.

Realistic Mathematics Education (RME) adalah salah satu pendekatan pembelajaran matematika yang berkaitan dengan kehidupan sehari-hari. Pada (wijaya, 2012: 20) menurut Frudenthal matematika merupakan suatu bentuk aktivitas manusia. Ciri-ciri dari RME yaitu: (1) Menggunakan konteks dunia nyata yaitu masalah konstekstual sebagai aplikasi dan titik tolak dari mana matematia yang diinginkan muncul. (2) Menggunakan model, yaitu belajar matematika berarti bekerja dengan matematika. (3) Menggunakan hasil dan kontruksi siswa sendiri, yaitu dalam menemukan konsep-konsep matematis, siswa diberikan kesempatan oleh guru. (4) Pembelajaran terfokus pada siswa, (5) Terjadi interaksi antara murid dan guru, yaitu meliputi kegiatan memecahkan masalah kontekstual yang realistik pada aktivitas pembelajaran.

Penggunaan alat pembelajaran untuk menunjang metode pembelajaran untuk melakukan atau menyajikan, menguraikan dan memberi latihan isi pelajaran kepada siswa untuk mencapai tujuan tertentu. Lembar Kerja Siswa (LKS) yang digunakan guru dalam Rencana Pelaksanaan Pembelajaran (RPP) merupakan salah satu bahan ajar dalam bentuk cetak yang digunakan oleh siswa sebagai alat untuk belajar secara mandiri dan digunakan seorang pengajar untuk memberikan materi kepada siswa secara runtut dan sesuai dengan Rencana Pelaksanaan Pembelajaran (RPP).

Bahan bajar merupakan segala informasi, alat, maupun teks yang disusun secara sistematis, yang menampilkan keseluruhan dari kompetensi yang akan dikuasai siswa sehingga tercipta suasana yang memungkinkan siswa untuk belajar tidak hanya mengetahui, tetapi juga melakukan (learning to do), menjadi (learning to be), hidup bersama (learning to live together) dengan tujuan, perencanaan sekaligus implementasi kurikulum (Prastowo, 2013:298). Bahan ajar adalah segala bentuk bahan yang digunakan dalam melaksanakan kegiatan pembelajaran di kelas (National Center for Vocational Education Research Ltd/National Center for Competency Based Training dalam (Majid, 2008: 174) .

Berdasarkan bpendapat di atas, dapat disimpulkan bahwa bahan ajar merupakan suatu materi pelajaran yang disusun sesuai materi yang akan diajarkan secara sistematis dan utuh untuk membantu tercapainya tujuan kurikulum dan dapat memudahkan siswa dan guru dalam melaksanakan pembelajaran. Sangat penting dalam merancang bahan ajar dalam proses pembelajaran karena bahan ajar yang dikembangkan harus mampu meningkatkan motivasi dan efektivitas penggunanya.

Berdasarkan hal-hal yang telah disampaikan tersebut, maka perlu dikembangkan suatu bahan ajar yang memberikan alternatif dalam pembelajaran matematika khususnya materi bangun ruang sisi tabung pada Rencana Pelaksanaan Pembelajaran. Tujuan dari penelitian ini adalah untuk mengetahui bagaimana efektifitas penerapan bahan ajar matematika pada materi bangun ruang tabung berbasis pendekatan Realistic Mathematics Education (RME) terhadap kemampuan pemecahan masalah matematika siswa pada materi bangun ruang tabung.

\section{METODE}

Metode penelitian yang digunakan dalam penelitian ini adalah metode kualitatif dengan jenis penelitian kepustakaan. Penelitian kepustakaan merupakan suatu jenis penelitian yang digunakan dalam pengumpulan informasi dan data secara mendalam melalui berbagai literatur, buku, catatan, serta hasil penelitian sebelumnya yang relevan untuk mendapatkan jawaban dan landasan teori mengenai masalah yang akan diteliti. 


\section{HASIL DAN PEMBAHASAN}

Bahan ajar bangun ruang tabung berbasis pendekatan RME ini berupa bahan ajar yang dirancang untuk memfokuskan pada penemuan rumus/konsep/prinsip dari masalah kontekstual di lapangan dan kemampuan pemecahan masalah matematis siswa. Bahan ajar ini dirancang setelah peneliti menyusun Rencana Pelaksanaan Pembelajaran (RPP) untuk materi bangun ruang sisi lengkung tabung dengan berbasis pendekatan RME.

a. Rencana Pelaksanaan Pembelajaran (RPP)

RPP dirancang dengan menggunakan pendekatan pembelajaran berbasis RME. RPP dimodifikasi agar sesuai dengan langkah RME dan prinsipnya yaitu menggunakan masalah kontekstual, menggunakan model, menggunakan hasil dan kontruksi siswa sendiri. Pembelajaran terfokus pada siswa, terjadi interaksi antara siswa dan guru serta interaksi siswa dengan siswa.

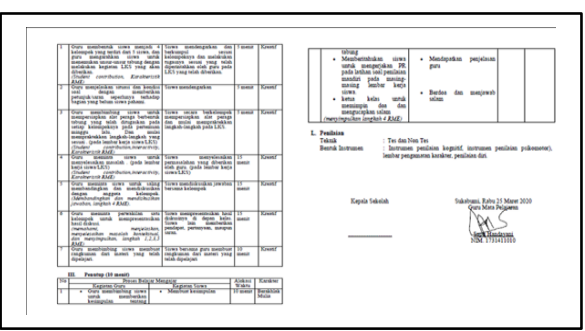

Gambar 1. Rencana Pelaksanaan Pembelajaran (RPP)

Dari gambar di atas dapat dilihat bahwa dalam RPP untuk materi bangun ruang sisi lengkung tabung berbasis pendekatan RME, terdapat langkah-langkah dan karakteristik RME dengan metode yang digunakan adalah ceramah, tanya jawab dan diskusi kelompok.

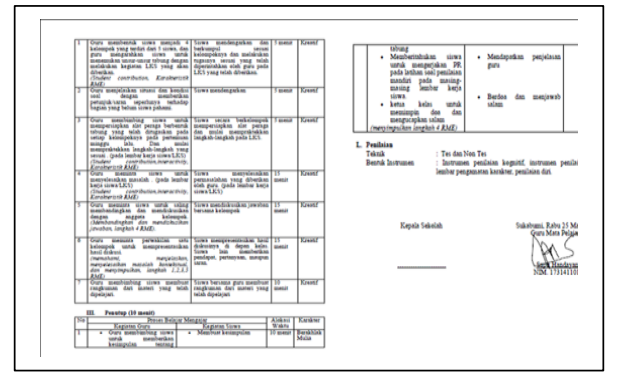

Gambar 2. Rencana Pelaksanaan Pembelajaran RPP

Pada kegiatan pembelajaran di dalam RPP tersebut, guru melakukan pembukaan seperti biasa dan menyampaikan tujuan pembelajaran dan hasil belajar yang ingin dicapai. Guru mulai mengkondisikan siswa dan menjelaskan prosedur pembelajaran sesuai RME. Karena RPP menggunakan metode diskusi kelompok, maka guru membentuk kelompok siswa dan siswa harus mengikuti kegiatan tersebut. Kegiatan ini sesuai dengan karakteristik RME yaitu Student Contribution, karena siswa berkontribusi dalam kegiatan ini. b. Bahan Ajar / Lembar Kerja Siswa (LKS)

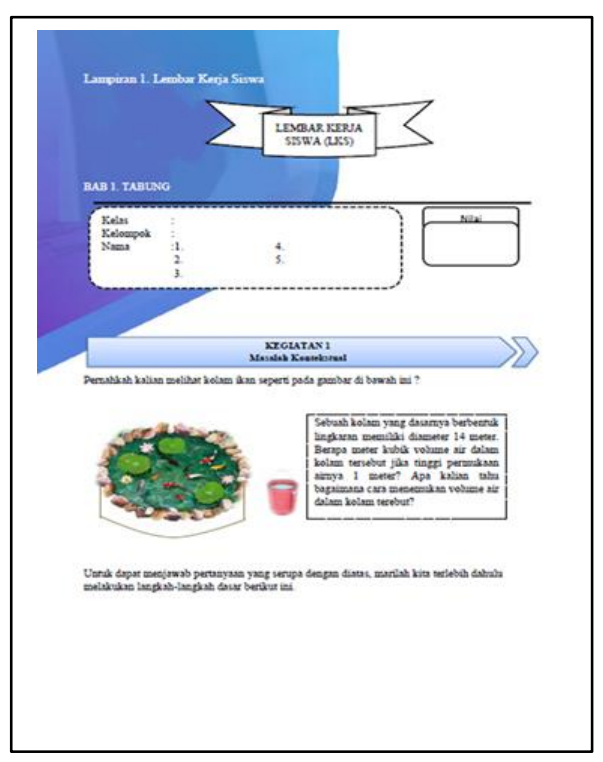

Gambar 3. Bahan Ajar (LKS)

Dari gambar di atas dapat dilihat bahwa dalam bahan ajar materi bangun ruang sisi lengkung tabung berbasis RME, siswa dikenalkan dengan masalah kontekstual yaitu pengalaman nyata bagi siswa. Dalam gambar di atas salah satunya adalah sebuah kolam ikan yang dasarnya berbentuk lingkaran sehingga kolam ikan tersebut berbentuk bangun ruang sisi lengkung tabung. Dari gambar kolam ikan tersebut terdapat unsur-unsur tabung yaitu selimut dan alas tabung. Dengan adanya kaitan antara pembelajaran matematika dengan masalah nyata yang terdapat pada lingkungan sekitar, siswa akan lebih termotivasi dalam mempelajari matematika. Dengan menyertakan masalah kontekstual. Secara bertahap, siswa dibimbing untuk menguasai konsep matematika. Diharapkan juga, dalam memecahkan suatu permasalahan yang disajikan, siswa dapat menggunakan daya nalar nya. Jadi dalam pembelajaran matematika, jika dapat menggabungkan dengan kehidupan sehari-hari siswa maka seorang guru matematika benar-benar berarti dan mengakui perannya dalam disiplin lainnya. Siswa ketika mengikuti pembelajaran matematika tidak terlepas dari pengalaman mereka sehari-hari. Oleh karena itu, menyertakan konsep matematika ke dalam kehidupan sehari-hari dapat menjadi alat yang efektif untuk pengembangan pemahaman di berbagai disiplin ilmu. 
Setelah mengenalkan masalah kontekstual tersebut, maka siswa diberikan soal untuk penemuan rumus/konsep/prinsip secara berkelompok, misalnya sebagai berikut:

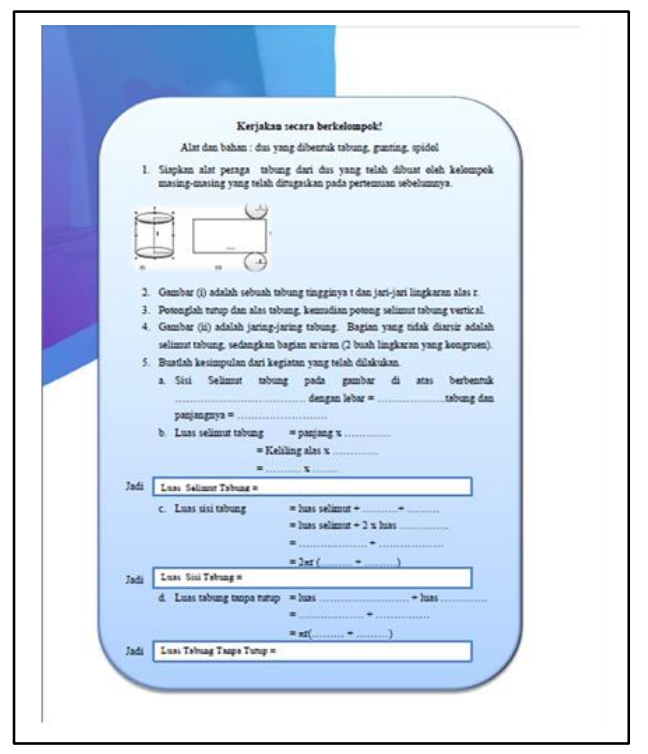

Gambar 4. Bahan Ajar (LKS)

Dengan siswa dilatih untuk penemuan rumus/konsep/prinsip dari masalah kontekstual secara berkelompok dan degan bimbingan dan petunjuk guru yang diberikan secara terbatas, setiap kelompok dapat menjawab dengan alur pemikiran yang berbeda tetapi dapat berdiskusi sehingga menjadi satu pemikiran dan dapat menemukan jawaban. Dalam bahan ajar ini juga diberikan beberapa soal pemecahan masalah sebagai berikut:

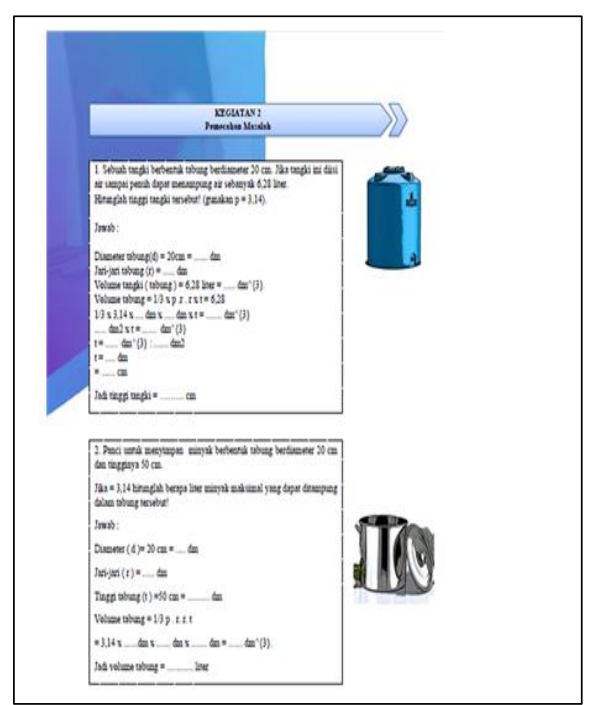

Gambar 5. Bahan Ajar (LKS)
Dari gambar di atas dapat dilihat bahwa bahan ajar matematika pada materi bangun ruang sisi engkung tabung berbasis pendekatan RME, siswa diberikan persoalan mengenai benda-benda sekitar dengan unsurunsur yang berbentuk tabung. Pada soal pertama gambar di atas ditunjukkan gambar sebuah tangki air. Tangki air merupakan tempat penyimpanan air yang biasa di gunakan di rumah-rumah. Tangki tersebut mempunyai unsur-unsur dari tabung, yaitu memiliki alas berbentuk lingkaran dan memiliki selimut tabung. Untuk soal yang kedua pada gambar di atas ditunjukkan panci. Panci merupakan salah satu alat yang digunakan untuk memasak. Panci juga mempunyai unsur- unsur dari tabung, yaitu memiliki alas berbentuk lingkaran dan selimut tabung. Dalam bahan ajar ini juga diberikan permasalahan mengenai benda-benda sekitar dengan membandingkan dua

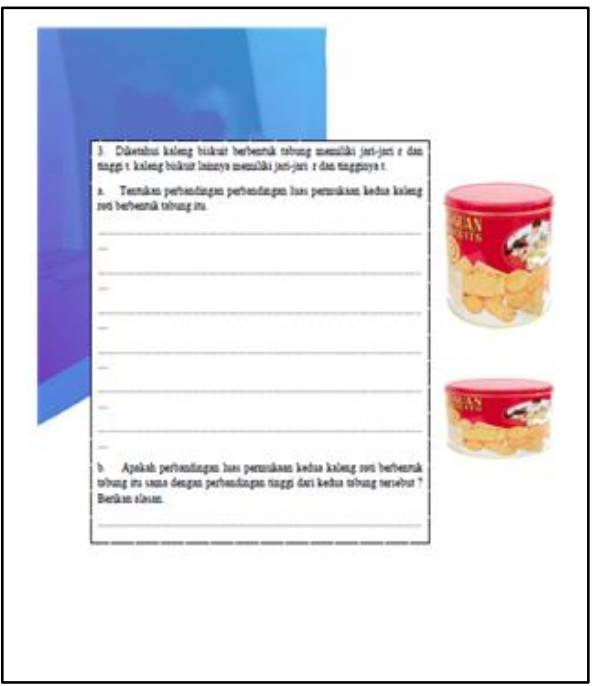

kaleng biskuit dengan ukuran yang berbeda besarnya seperti pada gambar berikut:

Gambar 6. Bahan Ajar (LKS)

Siswa akan menumbuhkan sikap kreatif dalam pembelajaran matematika jika siswa dilatih untuk memecahkan masalah matematika yang berkaitan dengan kehidupan sehari-hari, suasana ini dapat meningkatkan kemampuan siswa. Dalam pemecahan masalah, siswa di tuntut untuk memiliki kemampuan menciptakan gagasan-gagasan atau cara-cara baru berkenaan dengan permasalahan yang dihadapinya. Oleh karena itu, siswa memiliki kesempatan yang dangat terbuka untuk mengembangkan serta meningkatkan kemampuan berpikir melalui penyelesaian masalah-masalah yang bervariasi. Dalam bahan ajar ini siswa diberikan beberapa permasalahan, yaitu mampu mengidentifikasi unsur-unsur yang harus diketahui pada materi tabung, mampu merumuskan masalah situasi sehari-hari dalam matematika, Sebelumnya ditunjukkan langkah-langkah kegiatan 
pembelajaran pada RPP bahwa siswa di bagi ke dalam beberapa kelompok dan menggunakan bahan ajar ini sehingga siswa mampu bekolaboratif bersama-sama memahami permasalahan dan dapat menafsirkan solusi yang diperoleh secara kelompok. Oleh karena itu dengan menggunakan bahan ajar matematika pada materi bangun ruang tabung berbasis pendekatan RME ini, kemampuan pemecahan masalah siswa dapat terlatih dengan baik.

Dalam bahan ajar ini siswa dituntut untuk menemukan dan mengkontruksi bersama kelompoknya dengan cara melakukan penelitian dan percobaan dengan menggunakan benda-benda nyata. Misalnya seperti terlihat pada gambar 7 berikut:

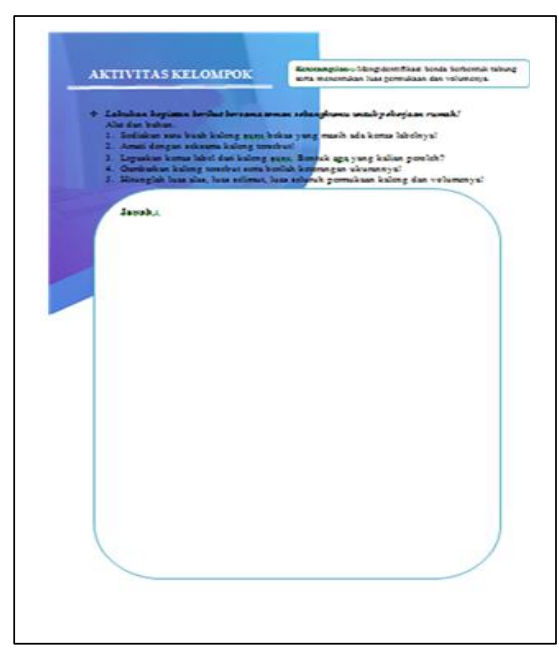

Gambar 7. Bahan Ajar (LKS)

Dalam gambar tersebut siswa diperintahkan untuk mencari sejenis kaleng susu yang masih memiliki label yang akan dijadikan bahan untuk melakukan penelitian dan percobaan benda nyata yang berbentuk tabung. Siswa diharuskan melakukan setiap langkah yang telah diperintahkan pada bahan ajar tersebut. Ketika sudah melakukan setiap langkah. Siswa dituntut untuk menemukan luas alas, luas selimut, luas seluruh permukaan kaleng dan volumenya.

Pembelajaran dengan bahan ajar ini diharapkan dapat meningkatkan motivasi siswa dalam belajar. Hal ini dikarenakan dengan menggunakan bahan ajar matematika pada materi bangun ruang sisi lengkung tabung berbasis pendekatan RME, selain siswa belajar tentang matematika siswa juga belajar mengenai fungsi perhitungan pada materi tabung pada benda ataupun permasalahan di sekitarnya. Selain itu siswa juga dilatih untuk menemukan dan mengkonstruk sendiri pengetahuannya tentang konsep-konsep matematika terutama pada materi bangun ruang sisi lengkung tabung dan siswa juga dibiasakan memecahkan suatu masalah dengan alur pemecahan masalah yang tepat.
Berdasarkan hasil penelitian tersebut maka dapat disimpulkan bahwa penerapan bahan ajar materi bangun ruang tabung berbasis pendekatan RME diharapkan dapat meningkatkan kemampuan pemecahan masalah matematis siswa, hal ini disebabkan karena:

1. Bahan ajar tersebut memfasilitasi siswa dalam menemukan kembali penemuan konsep matematika pada materi bangun ruang tabung.

2. Siswa diberikan permasalahan matematika yang berkaitan dengan materi bangun ruang tabung dengan masalah nyata ataupun benda nyata di sekitarnya.

3. Siswa termotivasi ikut pembelajaran karena bahan ajar yang digunakan dikaitkan dengan permasalahan yang ada di sekitar dan dikerjakan secara berkelompok.

4. siswa akan termotivasi untuk berdiskusi mengeluarkan pendapatnya dalam kelompoknya maupun antar kelompok mengenai konsep matematika pada materi bangun ruang tabung.

\section{SARAN}

Berdasarkan hasil penelitian penerapan bahan ajar yang di rancang pada RPP, maka peneliti merekomendasikan hasil penelitian kepada:

1. Peneliti selanjutnya dapat mengembangkan bahan ajar berbasis pendekatan RME pada materi yang berbeda dan lebih luas lagi cakupan bshasannya.

2. Peneliti selanjutnya dapat mengimplementasikan bahan ajar yang akan diterapkan tersebut ke beberapa sekolah bila telah mengembangkan bahan ajar dengan materi yang lebih luas lagi.

\section{DAFTAR PUSTAKA}

Harahap, Syahril,Muhammad,. (2017). Pengembangan Bahan Ajar Geometri Berbasis RME (Realistic Mathematic Education) Di STIKIP Tapanuli Selatan. Jurnal Education and development STKIP Tapanuli Selatan. Vol.7 No.5. ISSN: 2527-4295.

Sarbiyono. (2016). Penerapan Pendekatan Matematika Realistik Terhadap Kemampuan Pemecahan Masalah Matematis Siswa. Jurnal Reiew Pembelajaran Matematika.Vol 1. No. 2 163173.

Latifah,Siti. (2016).Skripsi Penerapan Pendekatan Realistik Mathematics Education (RME) Untuk Meningkatkan Kemampuan Pemecahan Masalah Matematis Pada Soal Cerita di SD.

\section{KESIMPULAN}


Repository Indonesia University of Education. 024/PGSD-Ref/9A.

Atika, dan Amir. (2016). Pengembangan LKS Berbasis
Pendekatan
RME
untuk

Menumbuhkembangkan Kemampuan Berpikir

Kritis Matematis Siswa. Suska Journalof Mathematics Education. Vol 2.No 2. 103-110.

Sarbiyono. (2015). Thesis (Master) Penerapan Pendekatan Matematika Realistik Terhadap Kemampuan Pemahaman Konsep dan Kemampuan Pemecahan Masalah Matematis siswa tahun pelajaran 2013-2014. Repository Universitas Terbuka.

Rohati. (2015). Pengembangan Perangkat Pembelajaran Berbasis Pendekatan Realistic Mathematics Education (RME) Pada Materi Volume Bangun Ruang Sisi Datar yang Mendukung Kemampuan Komunikasi Matematika Siswa di SMP. Edumatica.Vol 05. No.02. ISSN: 2088-2157.

Yarmayani,Ayu. (2016). Analisis Kemampuan Pemecahan Masalah Matematis Siswa Kelas XI MIPA SMA Negeri 1 Kota Jambi. Jurnal Ilmiah Dikdaya.Vol 6. No. 2 ISSN 2580-7463. 